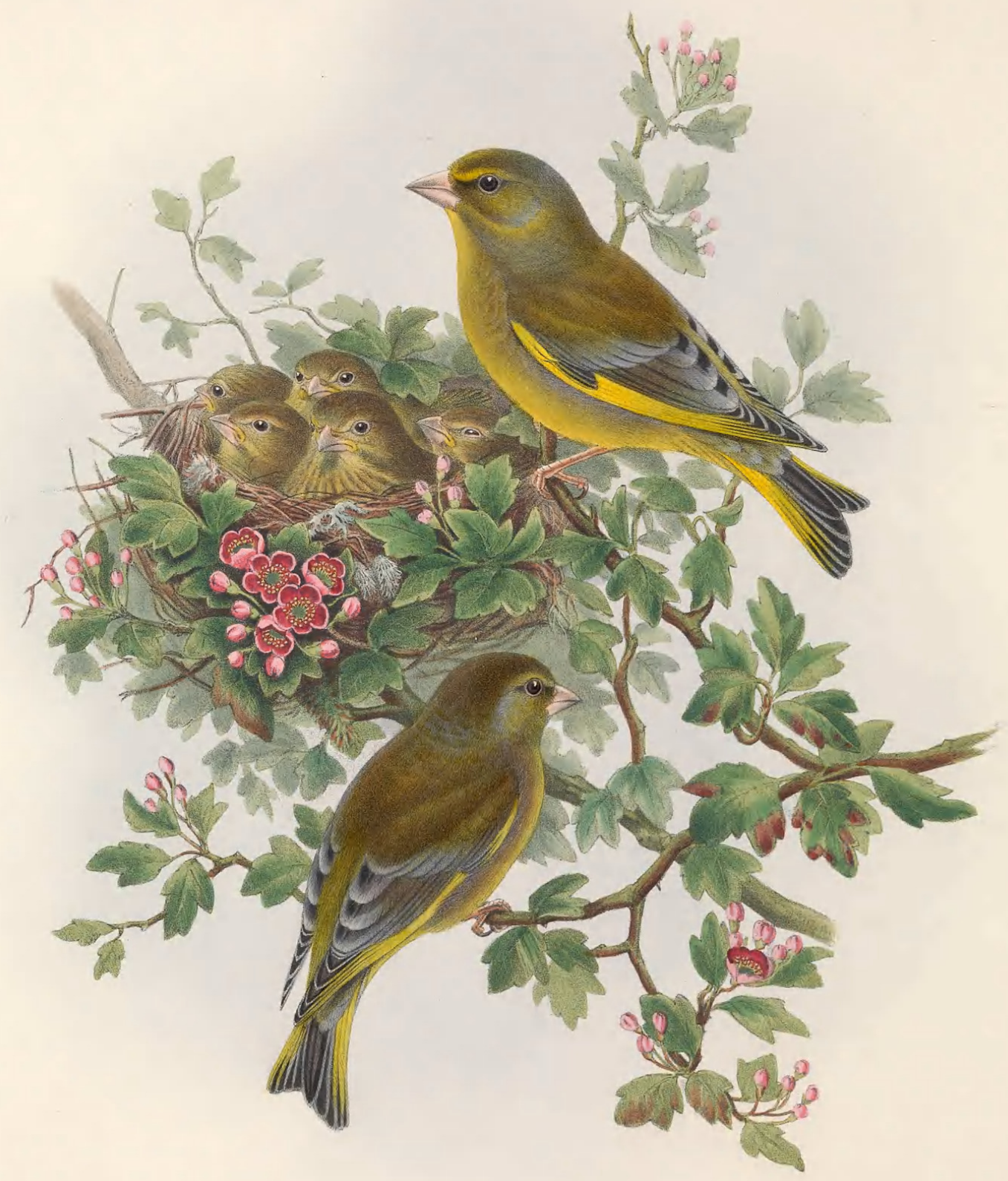




\section{LIGURINUS CHLORIS.}

\section{Greenfinch.}

Loxia chloris, Linn. Faun. Suec., p. 82.

Fringilla chloris, Temm. Man. d’Orn., 1815, p. 206

Ligurinus chloris, Koch, Baier. Zool., tom. i. p. 230.

Serinus chloris, Boie, Isis, 1822, p. 555.

Coccothraustes chloris, Steph. Cont. of Shaw's Gen. Zool., vol. xıv. p. 87

Linaria chloris, Macgill. Hist. of Brit. Birds, vol. i. p. 366.

Chlorospiza chloris, Bonap. Geog. \& Comp. List of Birds of Eur. and N. Amer., p. 30.

Chloris pinetorum, hortensis, et septentrionalis, Brehm, Vög. Deutschl., pp. 259, 260, 261, tab. 17. fig. 1.

_lavigaster, Swains. Class. of Birds, vol. ii. p. 281.

THE Greenfinch is strictly indigenous in our island. In winter it frequents the fields, hedgerows, and woods, and, if the weather becomes severe and the ground carpeted with snow, assembles in flocks round the farm-steadings and the immediate vicinity of houses. In spring and summer it is even still more familiar; for it then resorts to gardens and shrubberies, and often builds its nest and rears its young among the shrubs, even those close to the windows of our dwellings. Its dispersion over England, Scotland, and Ireland is so general that it would be superfluous to enumerate the localities in which it may be observed. On the continent of Europe, from the shores of the Mediterranean to Scandinavia, it is just as numerous as in England; and in North Africa, as far as the Atlas range, it is equally plentiful. I have also a specimen in my collection (a little smaller in size, and rather more brightly coloured) from Erzeroum; and, according to the Rev. H. B. Tristram, it is abundant in all the gardens of Southern Palestine ('Ibis,' 1859 , p. 33), is a very common winter visitant on the coasts, and abounds especially on Mount Carmel and on any wooded hills, but is rare in the interior, and disappears in the spring ('Ibis,' 1868, p. 206).

"The Greenfinch," says Yarrell, "is found in all the cultivated parts of England, Ireland, and Scotland, except, as stated by Macgillivray, the western and northern islands of the latter country. It is included among the birds of Denmark, Norway, and Sweden, but, according to M. Nilsson, is more numerous in Sweden in winter than in summer. It is abundant in all the countries of Southern Europe, and is found even as far as Madeira. In a south-eastern direction it was observed by Mr. Strickland to be numerous at Smyrna." Wright states that it is very common in flocks during winter at Malta ('Ibis,' 1864, p. 51), and Lord Lilford and Lieut. Sperling that it is resident and very numerous in Corfu, Santa Maura, and Greece, and in winter collects in flocks on the north coast of the Mediterranean ('Ibis,' 1860 , p. 138 ; 1864, p. 280). Dr. Giglioli observes that, in the neighbourhood of Pisa, in Italy, it frequents the tops of the white poplars which line the Piaggie and Cascine roads ('Ibis,' 1865, p. 57); and von Homeyer records, in the 'Journal für Ornithologie', that it occurs in the Balearic Isles just as in Europe. It does not extend to India ; neither is it enumerated in the lists of the birds of Amoorland or China. In Japan there are two nearly allied but quite distinct species.

The Greenfinch, as seen in our gardens during the month of April or at the time of pairing, is a very joyous and interesting bird. The male then displays himself to the greatest advantage, rising in the air with outspread wings and tail, frequently turning and pirouetting, as it were, and returning to the same tree or branch, uttering all the while its loud ringing whistle. During flight, the silvery under surface of the wings shows very conspicuously, and the fine yellow markings of the upper surface present a strong. contrast to the olive colouring of the body. "When paired," says Sir William Jardine, " they resort to the garden and shrubbery, breed in the various cover which is there afforded; and at this time the male may be seen in the morning, rising with slow or heavy strokes of the wing, uttering his simple note, and performing his long winding flight peculiar to the season of love. During winter they congregate in large flocks, feeding on various small seeds on the stubble-ground, and resorting towards nightfall to the vicinity of the plantations or evergreens surrounding some mansion, flying for a time around and clustering before taking up their roost on the top of some bare tree. Their sleeping-place is returned to night after night throughout the winter; and the flock may be seen taking up the perches in the same bushes with great regularity," Thompson, after remarking that the above account is in entire accordance with his observation on the favourite haunts of the Greenfinch, to which alone they will strictly apply, adds : - "By the plantation of shrubberies I have known this handsome bird to be attracted to, and soon become plentiful in a rather wild district near Belfast, from which it had previously been absent, the Portugal laurel (Prunus Lusitanica), with its dense foliage, being its favourite resort." 
With respect to the song of the Greenfinch, I find it so admirably described by the Rev. C. A. Johns in his 'British Birds in their Haunts,' that I cannot possibly do better than give the passage entire:- "The lively greenish yellow tint of the plumage on its throat and breast sufficiently distinguishes the Greenfinch from any other British bird; and its note, when once identified, can be confounded with no other song. Let any person who wishes to obtain a sight of one, walk anywhere in the country where there are trees, on a bright sunny day in May or June, and listen to a monotonous long-drawn croak, trying to pronounce the syllable 'twe-e-e.' No matter what other birds may be tuning their lays, the harsh monotone of the Greenfinch, if one be near, will be heard among them, harmonizing with none, and suggestive of heat and weariness. In a few seconds it will be repeated, without a shadow of variation either in tone or duration; and, if it be traced out, the author of the noise (music I cannot call it) will be discovered perched among the branches of a moderately high tree, repeating his mournful ditty with extreme complacency for an hour together. Very often it takes advantage of the midday silence of the groves, and pipes away without any other competitor than the Yellow-Hammer, whose song, like his own, is the constant accompaniment of sultry weather. The Greenfinch has another note, which is heard most frequently, but not exclusively, in spring. This is a simple plaintive chirp, which may be easily imitated by human whistling: it resembles somewhat one of the call-notes of the Canary-bird or Brown Linnet, and, being full and sweet, harmonizes with the woodland chorus far better than the monotonous croak described above. Another of the notes is a double one, and closely resembles that of the 'Pee-wit;' hence it is called, in some places, 'Pee-sweep.' '

We learn from Mr. George Dawson Rowley's communication to 'The Ibis' for 1862, p. 384, that the Greenfinch is one of the few Fringilline birds included among the foster-parents of the parasitical Cuckoo.

The situations resorted to for the purpose of nesting have been already mentioned; with regard to the nests themselves, they vary greatly in the materials of which they are composed, as will be seen from Thompson's description of one found by him in Ireland, Macgillivray's record of another taken by him in Scotland, and two or three by myself in England.

"A nest," says Thompson, "found in a beech hedge in the wild district, near Belfast, above mentioned, was so tastefully lined as to be considered worth preserving. Outwardly it was constructed of roots interwoven with mosses; but mixed with black and white hairs in the lining were swans-down and thistle-seed, this last being evidently made use of on account of its plumed appendages, all of which remained attached to the seed."

The Scotch nest is described by Macgillivray as " of good workmanship, being composed externally of fibrous roots, slender twigs, and straws, internally of finer materials of the same kind, intermixed with moss, and lined with hair of different kinds."

A nest, taken by myself near London, was built almost entirely of wool mixed with moss, a few twigs being interworen on the outside; while internally it was composed of very fine rootlets, wool, and a few feathers. A second, in the garden of John Noble, Esq., at Berry Hill, Taplow, had an outer framework of roughly interlaced roots, to which succeeded a course of closely interwoven fine rootlets and moss sparsely lined with horse-hair.

The eggs, which are from four to six in number, are of a bluish white, spotted at the larger end with purplish grey and blackish brown, and are about nine or ten lines in length, by six or seven in breadth.

"Although," says Thompson, "the Greenfinch cannot strictly be said to build in company, yet as many as twenty nests may occasionally be found in a moderate-sized slrubbery, and not unfrequently on the than of thesame plant."

The food of the Greenfinch consists of the seeds of various grasses, especially the cultivated kinds, and other plants. Occasionally the bird becomes troublesome by resorting to fields of newly-sown wheat; but Thompson tells us that it is "much fonder of the seed of the corn-marygold (Chrysanthemum segetum) than of the grain among which that handsome weed grows."

The sexes differ but little in their colouring, the general distribution of the tints being the same; but those of the female are less brilliant than those of the male, and the yellow of her undersurface does not extend on to the flanks. In spring the bill is nearly white, especially the basal portion of the under mandible, the tips and the culmen being clouded with a dusky hue. The nestlings are rendered conspicuous by the striation of the feathers of the undersurface ; these feathers are changed at an early period in the autumn, when the young brood very closely resemble their parents in their winter dress.

The Plate represents an adult of each sex and a nest of young birds on a branch of the pink-flowering May, all of the natural size. 


\section{$2 \mathrm{BHL}$ Biodiversity Heritage Library}

Gould, John. 1873. "Greenfinch, Ligurinus chloris [PI. 39]." The birds of Great Britain 3, -. https://doi.org/10.5962/p.323930.

View This Item Online: https://www.biodiversitylibrary.org/item/221726

DOI: https://doi.org/10.5962/p.323930

Permalink: https://www.biodiversitylibrary.org/partpdf/323930

\section{Holding Institution}

Smithsonian Libraries

\section{Sponsored by}

Biodiversity Heritage Library

\section{Copyright \& Reuse}

Copyright Status: Public domain. The BHL considers that this work is no longer under copyright protection.

This document was created from content at the Biodiversity Heritage Library, the world's largest open access digital library for biodiversity literature and archives. Visit BHL at https://www.biodiversitylibrary.org. 